\title{
OPTIMISATION OF SUPERCRITICAL CARBON DIOXIDE EXTRACTION OF LIPOPHILIC EXTRACT FROM ROSEHIPS
}

\author{
Lina Sernaite*, Dalia Urbonaviciene, Ceslovas Bobinas, Pranas Viskelis \\ Institute of Horticulture, Lithuanian Research Centre for Agriculture and Forestry, Kauno str., Babtai, Lithuania, \\ e-mail: l.sernaite@lsdi.lt
}

\begin{abstract}
Rosehips (Rosa canina) contain biologically active compounds, such as carotenoids, tocopherols, polyphenolics, and organic acids. Carotenoids are widespread pigments in plants, where they are involved in photosynthesis and photoprotection, but they are also found in human tissues where they may act as antioxidants or as immunomodulating, antimutagenic and tumour-preventing agents. Therefore, developments of processes of isolation of rosehips extracts with these compounds are of interest. In this study, the lipophilic extract of rosehips was obtained by supercritical fluid extraction with carbon dioxide under different extraction conditions. The aim of this work was to optimize the extraction process of lipophilic extracts from rosehips using pressures from 15 to $45 \mathrm{MPa}$, temperatures from 40 to $80{ }^{\circ} \mathrm{C}$ and extraction time from 60 to $180 \mathrm{~min}$, and to evaluate the yield of biologically active high-value compounds - carotenoids (lycopene and $\beta$-carotene). The content of total carotenoids in extracts was analysed by high-performance liquid chromatography. The optimal conditions in terms of maximising lipophilic extract yield were $75.2{ }^{\circ} \mathrm{C}, 44 \mathrm{MPa}, 115 \mathrm{~min}$. That allowed the recovery of $65 \%$ of the lipophilic extract in comparison to control.
\end{abstract}

Keywords: carotenoids, optimisation, rosehips, supercritical fluid extraction

\section{Introduction}

Rosehips, fruits of rose plants (Rosa sp.), are a proven source of carotenoids, polyphenols (triterpene acids, flavonoids, proanthocyanidins, catechin), essential fatty acids, galactolipids, folates, vitamin $\mathrm{A}, \mathrm{C}$ and $\mathrm{E}$, minerals $(\mathrm{Ca}, \mathrm{Mg}, \mathrm{K}, \mathrm{S}, \mathrm{Si}, \mathrm{Se}, \mathrm{Mn}$ and $\mathrm{Fe})$, and other valuable compounds (Fan et al., 2014; Patel, 2017).

Carotenoids are relevant micronutrients which could lead to health benefits while consuming fruits, vegetables, and other food rich in carotenoids (Olson, 1999; Radzevičius et al., 2016a). Significance of carotenoids in human health mainly appears through foods, cosmetics, nutraceuticals and pharmaceuticals. These lipophilic pigments naturally occur in some fruits and vegetables, and are accountable for typical colours (mostly yellow, orange and red) (Radzevičius et al., 2016b). It is already investigated their positive effect on health, prevention and protection against certain types of cancers, cardiovascular diseases and macular degeneration, as well as enhancing the immune function (Rao, Rao, 2007; Cazzonelli, 2011; Kadian, Garg, 2012).

The main carotenoids of rosehips are lycopene and $\beta$-carotene (Horvath et al., 2012), both of them are hydrophobic and can be dissolved in non-polar organic solvents, such as tetrahydrofuran, hexane, chloroform, and acetone, but are essentially insoluble in polar solvents, such as water and ethanol. The need for safer methods of obtaining carotenoids in the lipophilic extracts (extracted from natural plant materials) has led to supercritical fluid extraction (Zuknik et al., 2012). Supercritical fluid extraction (SFE) is an environmentally friendly, alternative to the conventional industrial solvent extraction method, which results in products without toxic solvent residues. Carbon dioxide is neither toxic nor flammable and could be acquired at high purity with low expenses. Because of these properties, it is one of the most frequently used supercritical fluid. Compounds that easily degrade under high temperature may be extracted with $\mathrm{CO}_{2}$ due to its reasonable critical temperature. Considering these characteristics, $\mathrm{SF}$ extraction with $\mathrm{CO}_{2}\left(\mathrm{SFE}-\mathrm{CO}_{2}\right)$ is a well suitable method for food, dye, pharmaceutical and cosmetic industries. Previous research on SFE- $\mathrm{CO}_{2}$ extraction from carotenoids-containing rosehip fruits had been reported by Illes et al. (1997), but the influence of extraction conditions on the total carotenoids and carotenoid composition in rosehips has not been examined yet. Several studies demonstrated that $R$. canina rosehips have a relevantly high content of carotenoids (Andersson et al., 2011). There is a necessity to optimize the process variables, including temperature, pressure, and extraction rate when developing SFE- $\mathrm{CO}_{2}$ extraction process for lipophilic extracts. However, the optimization of lipophilic extract yield and maximisation of carotenoids in obtained extracts from rosehips ( $R$. canina) fruit has not yet been reported. According to Machmudah et al. (2012), lipids are extracted with pigments. Moreover, co-extraction may occur, then the lipophilic extracts from tomato seeds may increase the solubility of the extracted pigments, including carotenoids. Extraction of rosehips could have the same results. Accordingly, lipophilic extracts were co-extracted in all cases where lycopene is obtained from tomato by-products containing tomato seeds. Thus, it contributes to the solubility of carotenoids using SFE- $\mathrm{CO}_{2}$ extraction.

The aim of this work was to optimize the extraction process of lipophilic extracts from rosehips using pressures from 15 to $45 \mathrm{MPa}$, temperatures from 40 to $80{ }^{\circ} \mathrm{C}$ and extraction time from 60 to $180 \mathrm{~min}$, and to evaluate the yield of biologically active high-value compounds - carotenoids (lycopene and $\beta$-carotene).

\section{Materials and Methods}

Sample preparation

Ripe rosehips ( $R$. canina sp.) were visually selected and harvested. Ripe fruits were collected in October from wild bushes growing in the Lithuania. 
Rosehips were dried using convective drying method. Drying was performed in a UDS-150/1 hot-air laboratory dryer (Utenos krosnys, Lithuania) at $39 \pm 1{ }^{\circ} \mathrm{C}$ and an air-flow rate of $1.5 \mathrm{~m} \mathrm{~s}^{-1}$. Dried rosehips with seeds were grounded to a powder with a knife mill GM200 (Retsch, Germany).

\section{Particle size distribution measurements}

Particle size distribution of rosehips powder was measured on a particle size analyser (Mastersizer, Hydro 2000S (A), United Kingdom) operating using a laser diffraction method, widely accepted as a standard technique. Particle assessment was performed by following the guidance of ISO13320-1 (1999). Water was used as a dispersant for wet analysis, dispersant refractive index was 1.33 , and particle refractive index was 1.53. The particles size of the dried rosehips powder obtained in our study was $\leq 0.2 \mathrm{~mm}$.

\section{Supercritical $\mathrm{CO}_{2}$ extraction}

The lipophilic extract from dried rosehips with seeds powder obtained by Soxhlet automated extraction (Behr Labor-Technik, Germany) with the mixture of chloroform and hexane $(1: 1, \mathrm{v} / \mathrm{v})$ as control. Soxhlet extraction was carried out for 15 hours. The solvents were removed in a rotary vacuum evaporator (Büchi, Flawil, Switzerland) at $42{ }^{\circ} \mathrm{C}$ and the residue was weighed with analytical balances. The $\mathrm{SFE}-\mathrm{CO}_{2}$ experiments were carried out using supercritical fluid extractor SFT-150 (Supercritical Fluid Technologies, USA). Each extraction was performed using a $25 \mathrm{~g}$ sample of rosehips powder. Each sample was loaded into a $500 \mathrm{~mL}$ thick-walled stainless-steel cylindrical extractor vessel with an inner diameter of $14 \mathrm{~mm}$ and a length of $320 \mathrm{~mm}$. The temperature of the extraction vessel was controlled by a surrounding heating jacket. The volume of $\mathrm{CO}_{2}$ consumed was measured by a ball float rotameter and a digital mass flow meter in standard litres per minute $\left(\mathrm{SL} \mathrm{min}^{-1}\right)$ at standard state $\left(\mathrm{P}_{\mathrm{CO}_{2}}=100 \mathrm{kPa}, \mathrm{T}_{\mathrm{CO}_{2}}=20^{\circ} \mathrm{C}, \rho_{\mathrm{CO}_{2}}=0.0018 \mathrm{~g} \mathrm{~mL}^{-1}\right)$. The process consisted of static $(10 \mathrm{~min})$ and dynamic extraction steps. The static extraction time was included in the total extraction time (Urbonaviciene, Viskelis, 2017).

\section{HPLC analysis of carotenoids}

The content of carotenoids (total lycopene and $\beta$-carotene) in lipophilic extracts was analysed by highperformance liquid chromatography (HPLC). HPLC was performed using a modified version of the different methods and systems (Heymann et al., 2013, MelendezMartinez et al., 2013; Urbonaviciene et al., 2015). For the analysis, $2 \mathrm{~g}$ of rosehip powders and oleoresins after SFE- $\mathrm{CO}_{2}$ extraction were dissolved in $50 \mathrm{~mL}$ hexane and tetrahydrofuran $(4: 1 \mathrm{~V} / \mathrm{V})$ with $1 \%$ butylated hydroxytoluene (BHT) solution. The HPLC system used was a Waters 2695 liquid separation module (Water Corporation, U.S.A.). Elution of materials was monitored by UV-Visible detector (UV-Vis, 2489, Water Corporation, U.S.A.). Detection of lycopene and $\beta$-carotene had been performed at wave lengths of 473 and $450 \mathrm{~nm}$, respectively. Chromatographic separations were performed on a RP-C30 column ( $5 \mu \mathrm{m}$, $250 \times 4.0 \mathrm{~mm}$, YMC Europe, Dinslaken, Germany) connected to a C30 guard column $(5 \mu \mathrm{m}, 10 \times 4.0 \mathrm{~mm}$, YMC Europe, Germany) using a flow rate of $0.65 \mathrm{~mL} \mathrm{~min}{ }^{-1}$. The chosen column temperature was $25^{\circ} \mathrm{C}$. The mobile phase used consisted of methanol (solvent A) and methyl-tert-butyl ether (solvent B). Samples were injected at $40 \%$ B (held $5 \mathrm{~min}$ ), and the gradient then had been changed to $83 \% \mathrm{~B}$ in $50 \mathrm{~min}$, then to $100 \% \mathrm{~B}$ in $5 \mathrm{~min}$ (held $10 \mathrm{~min}$ ) and to $40 \% \mathrm{~B}$ in $5 \mathrm{~min}$ (held $10 \mathrm{~min}$ ).

\section{Statistical analysis}

Response surface methodology (RSM) using central composite design (CCD) model was applied to determine optimal extraction conditions for SFE- $\mathrm{CO}_{2}$ extraction to maximize the yield of total lipophilic extract and carotenoids. Data was analysed and the model was established using tDesign - Expert 7.0. software (Stat-Ease Inc., Mineapolis, JAV). The number of experiments was calculated by the formula (1):

$$
N=\left(2^{f}+2 f+c\right)
$$

where $\mathrm{f}-$ the number of factor points; $\mathrm{c}-$ the number of centre points.

The data for CCD was fitted with a second order polynomial equation (2):

$$
\begin{aligned}
Y=\beta_{0} & +\sum_{i=1}^{4} \beta_{i} X_{i}+\sum_{i=1}^{4} \beta_{i i} X_{i}^{2}+ \\
& +\sum_{i} \sum_{j=i+1} \beta_{i j} X_{i} X_{j}
\end{aligned}
$$

where $\mathrm{Y}-$ the predicted response;

$\beta_{0}-$ a constant;

$\beta_{i}, \beta_{i i}, \beta_{i j}$ - coefficients for linearity;

$X_{i}$ and $X_{j}$-independent variables.

All experiments were performed in triplicate and each collected sample was analysed in duplicate. SPSS 20 Software (SPSS Inc., Chicago, USA) was used for assessing mean values and standard deviations of the experimental data. Statistical significance of the model and variables was determined at $5 \%$ probability level $(\mathrm{p}<0.05)$. The adequacy of the model was determined by evaluating the 'lack of fit' coefficient and the Fisher test value (F-value) obtained from the analysis of variance. Extractions at every point were performed in triplicate and in random order.

\section{Results and Discussion}

Maximum yield and a desirable composition could be achieved by optimisation of the process. Effects of independent parameters on the lipophilic extraction yield from dried rosehip powders were examined using half fraction factorial design: $\mathrm{SFE}-\mathrm{CO}_{2}$ extraction was carried out using pressures $(\mathrm{P})$ from 15 to $45 \mathrm{MPa}$, temperatures (T) from 40 to $80{ }^{\circ} \mathrm{C}$ and extraction time (t) from 60 to $180 \mathrm{~min}$ (Table 1). The highest yield of $2.18 \mathrm{~g} 100 \mathrm{~g}^{-1} \mathrm{DW}$ was obtained at $\mathrm{P}=44 \mathrm{MPa}$, $\mathrm{T}=75.2{ }^{\circ} \mathrm{C}, \mathrm{t}=115 \mathrm{~min}$, and it reached $65 \%$ of total extraction yields $\left(3.35 \quad \mathrm{~g} \quad 100 \quad \mathrm{~g}^{-1}\right)$ obtained by 
conventional extraction with a Soxhlet apparatus. Under these conditions, $65 \%$ of lipophilic extract could be obtained, whereas $35 \%$ of the lipophilic extract remains in the solid matrix. Szentmihalyi et al. (2002) was studying the recovery of oils from rosehips seeds (a by-product) and the highest extraction yield was

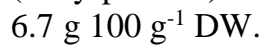

The analysis of the quadratic regression models for extract yield demonstrated that the model was significant $(\mathrm{p}<0.05)$ with an F-value of 56.8 and in this case the "lack of fit" was also significant relative to the pure error, with a $p$-value of $<0.001$. In the model it is presented that the factor with the largest effect on extract yield was $\mathrm{P}(\mathrm{p}<0.0001, \mathrm{~F}=248.52)$, followed by $\mathrm{T}$ $(\mathrm{p}<0.0001 ; \mathrm{F}=20.94)$ and $\mathrm{t} \quad(\mathrm{p}=0.004 ; \mathrm{F}=8.91)$. Interaction between factors pressure and temperature (PT) had significant effect on the yield $(\mathrm{p}<0.0001$, $\mathrm{F}=176.79$ ). The adequacy of the model was evaluated by the total determination coefficient $\left(R^{2}\right)$ value of 0.99 , indicating a reasonable fit of the model to the experimental data.

Table 1

Factors selected as independent variables for the optimization of SFE-COO

\begin{tabular}{lccccc}
\hline \multirow{2}{*}{$\begin{array}{l}\text { Symbols } \\
\text { (independent } \\
\text { variables) }\end{array}$} & $\mathbf{- 1 . 6 8 2}$ & $\mathbf{- 1}$ & $\mathbf{0}$ & $\mathbf{1}$ & $\mathbf{1 . 6 8 2}$ \\
\cline { 2 - 6 } $\mathrm{P}$ & 8.79 & 15 & 30 & 45 & 51.12 \\
$\mathrm{~T}$ & 31.72 & 40 & 60 & 80 & 88.28 \\
$\mathrm{t}$ & 35.15 & 60 & 120 & 180 & 204.85 \\
\hline $\mathrm{P}-$ extraction & $\begin{array}{l}\text { pressure, } \mathrm{MPa} ; \\
\mathrm{t}-\text { T }\end{array}$ & - extraction duration, min. & \multicolumn{5}{c}{ experature, ${ }^{\circ} \mathrm{C} ;$} \\
\end{tabular}

During the research, optimisation of pressure, temperature and extraction time to maximize the yield of lipophilic extracts, was made by applying RSM using CCD. The effect of $\mathrm{P}, \mathrm{T}$ and $\mathrm{t}$ on the extract yield is demonstrated in response surface plots, presented in Fig. 1 .

The following second-order polynomial model, denoting an empirical relationship between the dependent variables and the independent test variables $(\mathrm{P}, \mathrm{T}, \mathrm{t})$ was used (3):

$$
\begin{gathered}
Y=89.04-107.73 \times P+8.59 \times T-5.584 \times \\
t+4.95 \times P \times T-3.32 \times P \times t-0.02 \times T \times t- \\
31.85 \times P^{2}-0.35 \times T^{2}-0.10 \times t^{2}
\end{gathered}
$$

where $\mathrm{P}$-extraction pressure;

$\mathrm{T}$ - extraction temperature;

$\mathrm{t}$ - extraction duration.

The extraction yield is only one of several indicators for assessment of SFE-CO $\mathrm{CO}_{2}$ extraction efficiency. Another important indicator, especially when extracting ingredients for nutraceuticals and functional foods, is the amount of bioactive components detected in the isolated extract. Carotenoids are important bioactive compounds present in the lipophilic extract obtained from rosehips.
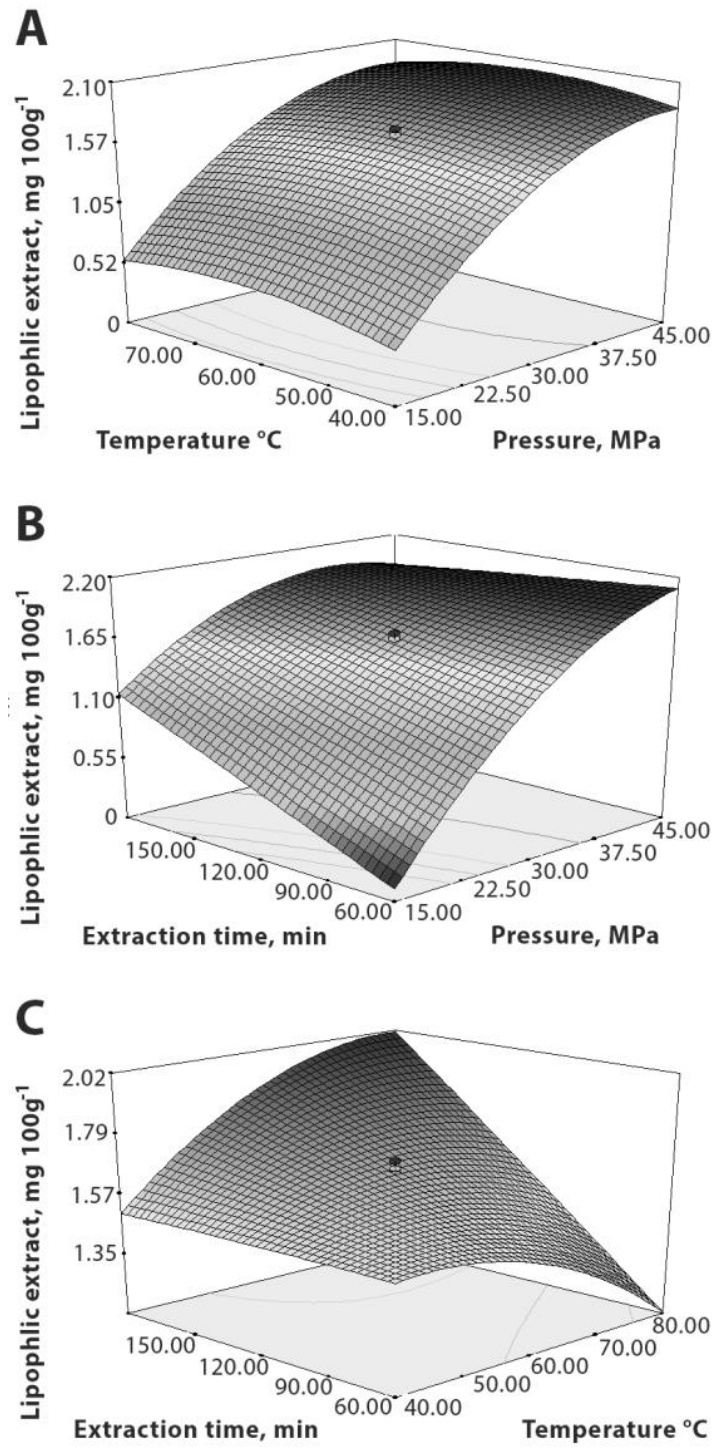

Figure 1. 3D response surface plots of $\mathrm{SFE}-\mathrm{CO}_{2}$ demonstrating the effects of independent variables on the lipophilic extract extraction yield of rosehips $\mathrm{A}$ - effect of extraction pressure and temperature; $\mathrm{B}$ - effect of extraction time and pressure; $\mathrm{C}$ - effect of extraction time and temperature

The extract yield was found to become higher with increased temperature, however the total $\beta$-carotene in the sample behaved contrarily (Table 2). $\beta$-carotene recovery at the lowest pressure $15 \mathrm{MPa}$ and the highest temperature $80^{\circ} \mathrm{C}$ was the lowest, whereas reducing temperature to $30{ }^{\circ} \mathrm{C}$ results in the increase of $\beta$-carotene recovery at constant pressure (Longo et al., 2012). However, it is evident that the increase in recovery of $\beta$-carotene is more significant when pressure is increasing at constant temperature, showing that pressure is the major factor influencing the recovery of $\beta$-carotene. Previously, Prado et al., (2014) concluded that in $\mathrm{SFE}-\mathrm{CO}_{2}$ extraction pressure is the most important factor influencing recovery of carotenoids, since carotenoids are large molecules with a low vapour pressure. These considerations are in agreement with 
our findings.

Results suggested that the model for obtaining the highest recovery of $\beta$-carotene in the extract $(39.1 \%$ w/w) were: $\mathrm{P}=45 \mathrm{MPa}$; $\mathrm{T}=63.3{ }^{\circ} \mathrm{C}, \mathrm{t}=150 \mathrm{~min}$.

Table 2

Fully coded central composite design, and lycopene and $\beta$-carotene yield in lipophilic fraction

\begin{tabular}{|c|c|c|c|c|c|}
\hline \multirow[b]{2}{*}{ 苞 } & \multirow[b]{2}{*}{$\mathbf{P}$} & \multirow[b]{2}{*}{$\mathbf{T}$} & \multirow[b]{2}{*}{$\mathbf{t}$} & \multicolumn{2}{|c|}{ Yield } \\
\hline & & & & 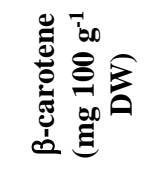 & 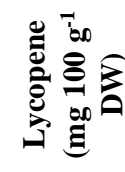 \\
\hline 1 & 45.0 & 80.0 & 60.0 & $11.2 \pm 4.6$ & $7.2 \pm 1.9$ \\
\hline 2 & 45.0 & 40.0 & 180.0 & $16.1 \pm 3.4$ & $4.4 \pm 1.0$ \\
\hline 3 & 15.0 & 80.0 & 180.0 & $12.3 \pm 2.1$ & $7.9 \pm 1.2$ \\
\hline 4 & 15.0 & 40.0 & 60.0 & $14.1 \pm 4.7$ & $5.8 \pm 0.5$ \\
\hline 5 & 8.8 & 60.0 & 120.0 & $11.2 \pm 2.8$ & $8.2 \pm 0.4$ \\
\hline 6 & 51.2 & 60.0 & 120.0 & $19.1 \pm 2.5$ & $4.1 \pm 0.2$ \\
\hline 7 & 30.0 & 31.7 & 120.0 & $13.1 \pm 4.5$ & $8.5 \pm 0.9$ \\
\hline 8 & 30.0 & 88.3 & 120.0 & $15.1 \pm 4.2$ & $5.4 \pm 0.3$ \\
\hline 9 & 30.0 & 60.0 & 35.2 & $10.0 \pm 3.1$ & $4.3 \pm 0.5$ \\
\hline 10 & 30.0 & 60.0 & 204.9 & $25.1 \pm 3.9$ & $2.3 \pm 0.5$ \\
\hline 11 & 30.0 & 60.0 & 120.0 & $13.9 \pm 2.0$ & $6.0 \pm 1.4$ \\
\hline 12 & 30.0 & 60.0 & 120.0 & $21.5 \pm 3.5$ & $5.9 \pm 1.4$ \\
\hline 13 & 30.0 & 60.0 & 120.0 & $16.2 \pm 2.4$ & $6.4 \pm 1.1$ \\
\hline 14 & 30.0 & 60.0 & 120.0 & $21.3 \pm 4.5$ & $7.5 \pm 1.0$ \\
\hline 15 & 30.0 & 60.0 & 120.0 & $20.2 \pm 2.8$ & $7.4 \pm 0.9$ \\
\hline
\end{tabular}

Values are represented as means \pm standard deviation $(n=3)$.

The approach of lycopene extraction was optimized in order to achieve the maximum concentration yield of the extract. In our study, the extraction temperature had been fixed between 40 and $80{ }^{\circ} \mathrm{C}$. It was determined different composition of the extract when extraction temperature varied from 40 to $60{ }^{\circ} \mathrm{C}$ and the pressure varied from $15 \mathrm{MPa}$ to $30 \mathrm{MPa}(\mathrm{p}<0.05)$. Subsequently, when the temperature was raised from 60 to $80^{\circ} \mathrm{C}$, decreased content of lycopene in the extract was observed (Table 2). Total lycopene in the obtained lipophilic extract could be lost due to several processes, such as degradation through oxidation (at the $80{ }^{\circ} \mathrm{C}$ ) and higher isomerisation (at 40 and $60{ }^{\circ} \mathrm{C}$ ). Findings of the research agree with previous studies (Lambelet et al., 2009), which investigated the thermal stability and isomerisation of lycopene under the conditions of 20$100{ }^{\circ} \mathrm{C}$. In our study, the highest recovery of lycopene in the extract $(45.2 \% \mathrm{w} / \mathrm{w})$ was reached under extraction conditions of: $\mathrm{P}=30 \mathrm{MPa} ; \mathrm{T}=34.5^{\circ} \mathrm{C}, \mathrm{t}=120 \mathrm{~min}$.

\section{Conclusions}

The optimum conditions in terms of lipophilic extract extraction yield were obtained at a temperature of $75.2^{\circ} \mathrm{C}$, a pressure of $44 \mathrm{MPa}$ and a time of $115 \mathrm{~min}$, and allowed the recovery of $65 \%$ of the extractable lipophilic extract.

\section{References}

1. Andersson S.C., Rumpunen K., Johansson E., Olsson M.E. (2011) Carotenoids content and composition in rose hips (Rosa spp.) during ripening, determination of suitable maturity marker and implications for health promoting food products. Food Chemistry, Vol. 128, p. 689-696.

2. Cazzonelli C.I. (2011) Carotenoids in nature: insights from plants and beyond. Functional Plant Biology, Vol. 38(11), p. 833-847.

3. Fan C., Pacier C., Martirosyan D.M. (2014) Rose hip (Rosa canina L): A functional food perspective. Functional Foods in Health and Disease, Vol. 4(12), p. 493-509.

4. Heymann T., Raeke J., Glomb M.A. (2013) Photoinduced isomerization of lycopene and application to tomato cultivation. Journal of Agricultural and Food Chemistry, Vol. 61(46), p. 11133-11139.

5. Horvath G., Molnar P., Rado-Turcsi E., Deli J., Kawase M., Satoh K., Molnar J. (2012) Carotenoid composition and in vitro pharmacological activity of rose hips. Acta Biochimica Polonica, Vol. 59(1), p. 129-132.

6. Illes V., Szalai O., Then M., Daood H., Perneczki S. (1997) Extraction of hiprose fruit by supercritical $\mathrm{CO}_{2}$ and propane. The Journal of Supercritical Fluids, Vol. 10(3), p. 209-218.

7. ISO 13320-1 (1999) Particle size analysis - Laser diffraction methods - Part 1: General principles.

8. Kadian S.S., Garg, M. (2012) Pharmacological effects of carotenoids: A review. International Journal of Pharmaceutical Sciences and Research, Vol. 3(1), p. $42-48$.

9. Lambelet P., Richelle M., Bortlik K., Franceschi F., Giori A.M. (2009) Improving the stability of lycopene Z-isomers in isomerised tomato extracts. Food chemistry, Vol. 112(1), p. 156-161.

10. Longo C., Leo L., Leone A. (2012) Carotenoids, fatty acid composition and heat stability of supercritical carbon dioxide-extracted-oleoresins. International Journal of Molecular Sciences, Vol. 13(4), p. 4233-4254.

11. Machmudah S., Zakaria, Winardi S., Sasaki M., Goto M., Kusumoto N., Hayakawa K. (2012) Lycopene extraction from tomato peel by-product containing tomato seed using supercritical carbon dioxide. Journal of Food Engineering, Vol. 108(2), p. 290-296.

12. Melendez-Martinez A.J., Stinco C.M., Liu C., Wang X.D. (2013) A simple HPLC method for the comprehensive analysis of cis/trans (Z/E) geometrical isomers of carotenoids for nutritional studies. Food Chemistry, Vol. 138(2), p. 1341-1350

13. Olson J. A. (1999) Carotenoids and human health. Archivos Latinoamericanos de Nutrición, Vol. 49, p. 7-11.

14. Patel S. (2017) Rose hip as an underutilized functional food: Evidence-based review. Trends in Food Science \& Technology, Vol. 63, p. 29-38.

15. Prado J.M., Veggi P.C., Meireles M.A.A. (2014) Extraction methods for obtaining carotenoids from vegetables-review. Current Analytical Chemistry, Vol. 10(1), p. 29-66.

16. Radzevičius A., Viškelis P., Viškelis J., Karklelienè R., Juškevičiené D., Duchovskis P. (2016a) Tomato biochemical composition and quality attributes in different maturity fruits. Acta Scientiarum Polonorum. Hortorum Cultus (Ogrodnictwo), Vol. 15(6), p. 221-231.

17. Radzevičius A., Viškelis J., Karklelienè R., Juškevičienè D., Viškelis P. (2016b) Determination of tomato quality attributes using near infrared spectroscopy and reference analysis. Zemdirbyste-Agriculture, Vol. 103(1), p. 91-98.

18. Rao A.V., Rao L.G. (2007) Carotenoids and human health. Pharmacological Research, Vol. 55(3), p. 207-216. 
19. Szentmihalyi K., Vinkler P., Lakatos B., Illés V., Then M. (2002) Rose hip (Rosa canina L.) oil obtained from waste hip seeds by different extraction methods. Bioresource Technology, Vol. 82(2), p. 195-201.

20. Urbonaviciene D., Viskelis P. (2017) The cis-lycopene isomers composition in supercritical $\mathrm{CO}_{2}$ extracted tomato by-products. LWT-Food Science and Technology, Vol. 85(B), p. 517-523.
21. Urbonaviciene D., Viskelis P., Viskelis J., Bobinas C. (2015) Stability of tomato lycopene under thermal- and light-irradiation treatments in an oil-based model system. Zemdirbyste-Agriculture, Vol. 102(2), p. 185-192.

22. Zuknik M.H., Norulaini N.N., Omar A.K.M. (2012) Supercritical carbon dioxide extraction of lycopene: A review. Journal of Food Engineering, Vol. 112(4), p. 253-262. 